\title{
Mechanical Properties of Hot Rolled Ribbed and Plain Steel Rods
}

\author{
${ }^{1}$ SHUAIB, MA; ${ }^{1}$ AJAO, KR; ${ }^{1,2 *}$ OLADOSU, KO \\ ${ }^{1}$ Centre for Sustainable Energy, ${ }^{2}$ Department of Mechanical Engineering, Kwara State University, Malete, Kwara State, Nigeria \\ *Corresponding Author Email: kamoru.oladosu@kwasu.edu.ng
}

\begin{abstract}
This study focuses on microstructure and mechanical behaviour of 3PS (Semi-killed mild steel) hot rolled ribbed and plain carbon steel. 3PS billet steel samples and hot rolled ribbed and plain steel rods of different heat numbers and profiles were characterized for its chemical composition, microstructure, and tensile behaviour. The composition analysis of 5 (five) 3PS billet samples shows that there was no appreciable variation in chemical composition of the hot-rolled plain and ribbed steel rods. The microstructures of as-received steel billet (3PS) examination revealed large grains of ferrite and pearlite while those of hot-rolled 3 PS mild steel samples of different heat numbers contain smaller grains of ferrite and some amount of pearlite. The results also indicated that yield and ultimate tensile strength reach maximum values (492 and $361 \mathrm{~N} / \mathrm{mm}^{2}$ ) at $0.31 \%$ elongation for heat number 43 while maximum values for heat number $56\left(478\right.$ and $\left.362 \mathrm{~N} / \mathrm{mm}^{2}\right)$ at $0.33 \%$ respectively. The ribbed steel rod of the same diameter as plain steel exhibit slightly better mechanical properties with higher values of yield and ultimate tensile strength. There is consistency in the chemical composition of the as-received billet and the hot rolled products.
\end{abstract}

\section{DOI: https://dx.doi.org/10.4314/jasem.v25i5.20}

Copyright: Copyright $\odot 2021$ Shuaib et al. This is an open access article distributed under the Creative Commons Attribution License (CCL), which permits unrestricted use, distribution, and reproduction in any medium, provided the original work is properly cited.

Dates: Received: 20 March 2021; Revised: 27 April 2021; Accepted: 07 May 2021

Keywords: Semi-killed mild steel, plain carbon steel, hot rolling, Mechanical characterization.

Plain carbon steels account for about $80 \%$ of all metals used for industrial applications (Mridha, 2016; Aggen et al., 2018) because of their low costs and ease of fabrication (Callister Jr. and Rethwisch, 2012). They can be formed into desired shapes with precise specifications through mechanical processes such as rolling and forging (Bell, 2017; Materials, 2012; Charlie, 1996; Atanda et al., 2015). Plain carbon steels are machinable, workable and heat treatable providing a wide range of mechanical properties such as yield strengths (200-300 MPa) (Hata et al., 2004). On the basis of heat treatment, killed, semi-killed and rimmed steels can be produced. Semi-killed steel is characterised by variable degrees of uniformity in composition which is intermediate between killed and rimmed steels. Typically, more gas is evolved in semikilled steel than in killed steel but less than in rimmed or capped steel. For all practical purposes, steels are categorized based on the amount of carbon contents which are hypoeutectoid steels (0.025-0.8 wt\% C), eutectoid steel $(0.8 \mathrm{wt} \% \mathrm{C})$ and hypereutectoid steels (>0.8 wt \% C) (Cheng et al., 2013). The properties of hot rolled ribbed and plain steel rods are influenced by several processing parameters such as degree of rolling and temperature among others. Zhuang and Di (2006) showed that the degree of rolling and temperatures significantly influenced microstructural and mechanical properties of hot-rolled multiphase steels. Polygonal ferrite, granular bainite, and a considerable amount of stabilized austenite were obtained by thermo mechanical processing. The results also indicated that ultimate tensile strength and total elongation reached maximum values of $791 \mathrm{MPa}$ and $36 \%$, respectively. The grain refinement as the only commercially available conventional technique which improves strength and ductility at same time was reported by (Zhuang and Di, 2006). They have noticed an excellent relationship between yield stress and grain size in the development of high strength low alloy (HSLA) steels. His finding shows that coarse grained steel has better hardenability than fine grained steel. Obikwelu, (1987) investigated the optimization of mechanical properties of rolled products and discovered that most mills in developing nation of the world still operated on the basis of conventional rolling which was devoid of modern facilities offered by controlled rolling. He observed that conventional mills were not executed along with the necessary temperature monitoring with a view to controlling the evolved microstructures. Saroj, (2010) reported that steel bars produced through conventional rolling often demonstrated low mechanical properties. He noticed that inter-stand temperature such that the desired initial austenite grain size is achieved and this would ensure that appropriate of morphology, grain size and texture during cooling of the bars. Zhang et al. (2017) reported effect of rolling process parameters on the mechanical properties of hot-rolled St60Mn steel. They concluded

*Corresponding Author Email: kamoru.oladosu@kwasu.edu.ng 
that increasing the rolling strain rate from $6.02851 \mathrm{x}$ $10^{3} \mathrm{~s}^{-1}$ to $6.10388 \times 10^{3} \mathrm{~s}^{-1}$ using $\%$ total deformation of $99 \%$ and finish rolling temperature of $958{ }^{\circ} \mathrm{C}$ enhanced the mechanical properties of St60 Mn steel. In the light of the above, current study focuses the effect of hot rolling on the mechanical properties and hot rolling of industrial products (steel rods of different profiles).

\section{MATERIALS AND METHODS}

Five samples of semi-killed mild steel (3PS) (billets steel grade with different heat treatment numbers and hot rolled products of the different profiles) were prepared at Ajaokuta Steel Company Limited, Kogi State, Nigeria. The standard composions of similar samples based on the laboratory's reports submitted to the Industry-German standard (DIN 380-94) are provided in Table 1.

Table 1: Chemical Composition based on Laboratory's reports submitted to the Industry -German standard (DIN 380-94)

\begin{tabular}{llllllll}
\hline $\begin{array}{l}\text { Heat } \\
\text { No. }\end{array}$ & $\begin{array}{l}\text { Steel } \\
\text { Grade }\end{array}$ & $\begin{array}{l}\text { Profile } \\
\text { mm }\end{array}$ & \multicolumn{5}{c}{ Chemical Composition } \\
\hline & & & C & Si & Mn & Pb & S \\
\hline 036 & 3PS & 125 & 0.161 & 0.059 & 0.314 & 0.009 & 0.013 \\
043 & 3PS & 125 & 0.156 & 0.051 & 0.513 & 0.009 & 0.013 \\
056 & 3PS & 125 & 0.183 & 0.056 & 0.552 & 0.009 & 0.013 \\
058 & 3PS & 125 & 0.164 & 0.055 & 0.490 & 0.008 & 0.012 \\
061 & 3PS & 125 & 0.172 & 0.070 & 0.567 & 0.045 & 0.041 \\
\hline
\end{tabular}

The samples (measured $40 \times 50 \times 10 \mathrm{~mm}^{3}$ ) were unidirectionally hot rolled at a temperature of $1045^{\circ} \mathrm{C}$ for three passes such that a $2 \mathrm{~mm}$ thickness reduction was achieved after each pass. The samples were characterized for microstructure, ultimate tensile and yield strength before and after hot rolling using optical microscope and computer controlled servo-hydraulic tensile testing machine, respectively. The samples for microscopy were prepared by grinding and mechanical polishing followed by etching in picral reagent. The fineness of lamellar structure was measured by the true interlamellar spacing, $\lambda_{0}$ (Ridley, 1984) while the grain size and large $\alpha$ platelets were estimated from the optical images. Tensile tests were carried out at room temperature by a computer-controlled servo-hydraulic facility (Instron model 8502) at a crosshead rate of 1 $\mathrm{mm} / \mathrm{min}$ using samples machined following ASTME8 standard.

\section{RESULTS AND DISCUSSION}

Chemical compositions of the samples: The compositions of the samples (Table 2) are similar to the DIN 380-94 standard composition (Table 1) indicating that the samples comform with the industry's standard. The implications of variance in carbon contents could lead to decrease in ductility, machinabilty and weldability of the steel. Similarly, the manganese which is also a neccesity for the process of hot rolling of steel and changes in their contents could steered to increase in the hardenability and tensile strength but decreases in ductilty of steel (Aghamir et al., 2018).

Microstructure and grain size analysis: Figure 1 shows the micrograph of as received $(a, b)$ and hot rolled (c,d) steel samples for heat number 43 and 56. The as received steel samples indicated large grains of ferrite and pearlite while hot rolled 3 PS mild steel micrographs appear to contain smaller grains of ferrite and some amount of pearlite. The finer grain size of the hot rolled 3PS steel samples indicates improved yield strength and grain refinement. Table 3 and Table 4 present tensile test and composition analysis of mild steel samples for heat number 43 and 56 after hot rolling. The yield strength (YS), ultimate tensile strength (US) and percentage elongation for asreceived before hot rolling 3PS (Heat number 43) were $333 \mathrm{~N} / \mathrm{mm}^{2}, 461 \mathrm{~N} / \mathrm{mm}^{2}$ and $0.35 \%$, while for (Heat number 56 ) were $316 \mathrm{~N} / \mathrm{mm}^{2}, 445 \mathrm{~N} / \mathrm{mm}^{2}$ and $0.36 \%$ respectively.
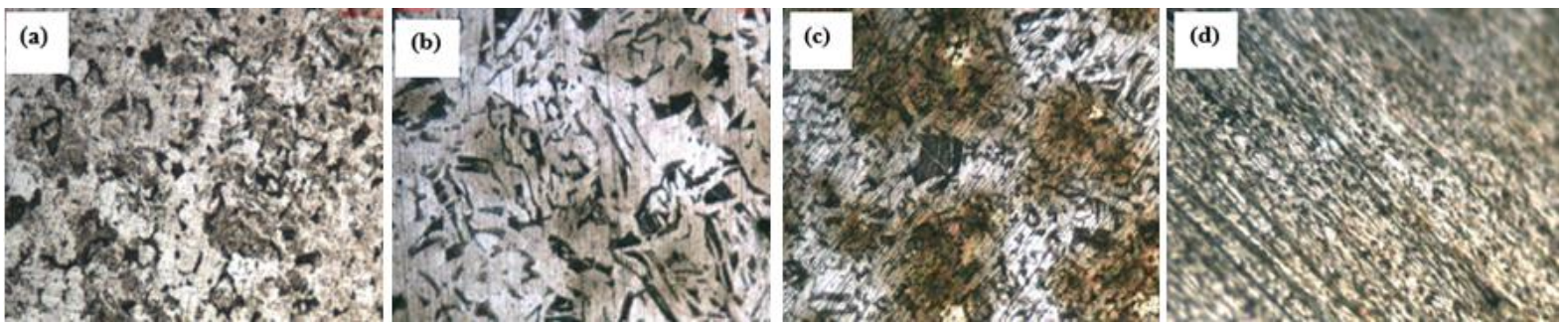

Fig 1: Optical micrograph of (a) as received billet heat No 43 (b) as received billet heat No 56 (c) Hot rolled steel rod heat No 43 (d) Hot rolled steel rod heat No 56 
Table 2: Tensile test and composition analysis of mild steel samples before hot-rolling

\begin{tabular}{|c|c|c|c|c|c|c|c|c|c|c|}
\hline \multirow{2}{*}{$\begin{array}{l}\text { Heat } \\
\text { No. }\end{array}$} & \multirow{2}{*}{$\begin{array}{l}\text { Steel } \\
\text { Grade }\end{array}$} & \multicolumn{2}{|c|}{$\begin{array}{l}\text { Profile YS 1 } \\
\mathrm{mm} \quad \mathrm{N} / \mathrm{mm}\end{array}$} & \multirow{2}{*}{$\begin{array}{l}\text { UTS } \\
\mathrm{N} / \mathrm{mm}^{2}\end{array}$} & \multirow{2}{*}{$\begin{array}{l}\text { Elongation } \\
\%\end{array}$} & \multicolumn{5}{|c|}{ Chemical composition } \\
\hline & & & & & & $\mathrm{C}$ & $\mathrm{Si}$ & Mn & $\mathbf{P b}$ & $\mathrm{S}$ \\
\hline 036 & 3PS & 125 & 290 & 417 & 0.39 & 0.161 & 0.059 & 0.314 & 0.009 & 0.013 \\
\hline 043 & & & 332 & 461 & 0.35 & & & & 0.009 & 0.0 \\
\hline 05 & 3PS & 12 & 316 & 445 & 0.36 & 0.183 & 0.0 & 0.552 & 0.009 & 0.013 \\
\hline 058 & 3PS & 125 & 330 & 445 & 0.34 & 0.164 & 0.05 & 0.490 & 0.008 & 0.012 \\
\hline 061 & 3PS & 125 & 303 & 445 & 0.40 & 0.172 & 0.070 & 0.567 & 0.045 & 0.041 \\
\hline
\end{tabular}

Table 3: Tensile test and composition analysis of mild steel samples after hot-rolling Heat No 43

\begin{tabular}{|c|c|c|c|c|c|c|c|c|c|c|c|}
\hline $\begin{array}{l}\text { Heat } \\
\text { No. }\end{array}$ & $\begin{array}{l}\text { Steel } \\
\text { Grade }\end{array}$ & $\begin{array}{l}\text { Profile } \\
\text { mm }\end{array}$ & $\begin{array}{l}\mathrm{YS} \\
\mathrm{N} / \mathrm{mm}^{2}\end{array}$ & $\begin{array}{l}\text { UTS } \\
\text { N/mm }\end{array}$ & $\begin{array}{l}\text { Elongation } \\
\%\end{array}$ & MILL & \multicolumn{5}{|c|}{ Chemical composition } \\
\hline & & & & & & & $\mathbf{C}$ & Si & Mn & $\mathbf{P b}$ & $\mathbf{S}$ \\
\hline 043 & 3PS & N12 & 333 & 458 & 0.35 & WRM & 0.170 & 0.053 & 0.055 & 0.0091 & 0.012 \\
\hline 043 & 3PS & N10 & 339 & 463 & 0.34 & WRM & 0.241 & 0.070 & 0.567 & 0.045 & 0.041 \\
\hline 043 & 3PS & N8 & 358 & 490 & 0.32 & WRM & 0.163 & 0.054 & 0.556 & 0.0094 & 0.013 \\
\hline 043 & 3PS & $\varnothing 08$ & 361 & 492 & 0.31 & WRM & 0.163 & 0.054 & 0.556 & 0.0094 & 0.013 \\
\hline
\end{tabular}

Table 4: Tensile test and composition analysis of mild steel samples after hot-rolling Heat No 56

\begin{tabular}{|c|c|c|c|c|c|c|c|c|c|c|c|}
\hline $\begin{array}{l}\text { Heat } \\
\text { No. }\end{array}$ & $\begin{array}{l}\text { Steel } \\
\text { Grade }\end{array}$ & $\begin{array}{l}\text { Profile } \\
\text { mm }\end{array}$ & $\begin{array}{l}\text { YS } \\
\text { N/mm }\end{array}$ & $\begin{array}{l}\text { UTS } \\
\text { N/mm }\end{array}$ & $\begin{array}{l}\text { Elongation } \\
\%\end{array}$ & MILL & \multicolumn{5}{|c|}{ Chemical composition } \\
\hline & & & & & & & $\mathbf{C}$ & Si & Mn & $\mathbf{P b}$ & $\mathbf{S}$ \\
\hline 056 & 3PS & N12 & 316 & 446 & 0.36 & WRM & 0.171 & 0.054 & 0.056 & 0.0091 & 0.012 \\
\hline 056 & 3PS & N10 & 317 & 454 & 0.35 & WRM & 0.170 & 0.053 & 0.555 & 0.0091 & 0.012 \\
\hline 056 & 3PS & N08 & 336 & 460 & 0.34 & WRM & 0.160 & 0.053 & 0.556 & 0.094 & 0.013 \\
\hline 056 & 3PS & $\varnothing 08$ & 362 & 478 & 0.33 & WRM & 0.160 & 0.053 & 0.556 & 0.094 & 0.013 \\
\hline
\end{tabular}

The carbon content was $0.156 \%$ and $0.183 \%$ which is within the range of mild steel (Zhuang and $\mathrm{Di}$, 2006). The chemical analysis on hot rolled steel rods of different profiles revealed that the values of YS and US decreases with decrease in the profiles of the hot rolled steel rods. By comparison of 3PS as received with hot rolled steel for heat number 43 and 56, it is clearly from the Table 2-3 that the YS, US and percentage elongation of heat number 43 and at $12 \mathrm{~mm}$ profile is increased by $0.3 \%$ in YS, $0.65 \%$ in US and $0.35 \%$ in elongation while at $8 \mathrm{~mm}$ profile is increased by $8 \%$ in YS, $6.3 \%$ in US and $0.31 \%$ in elongation. The YS, US and percentage elongation of heat number 56 and at $12 \mathrm{~mm}$ profile is increased by $4.8 \%$ in YS, $2.62 \%$ in US and $0.35 \%$ in elongation while at $8 \mathrm{~mm}$ profile is increased by $0.33 \%$. The yield and ultimate tensile strength reach maximum value of $492 \mathrm{~N} / \mathrm{mm}^{2}$ and $361 \mathrm{~N} / \mathrm{mm}^{2}$ for heat number 43 while $478 \mathrm{~N} / \mathrm{mm}^{2}$ and $362 \mathrm{~N} / \mathrm{mm}^{2}$ for heat number 56 at both a profile of $8 \mathrm{~mm}$ respectively (Figure 2). These results indicated that yield and the ultimate tensile strength increases with decrease in profile of mild steel samples.
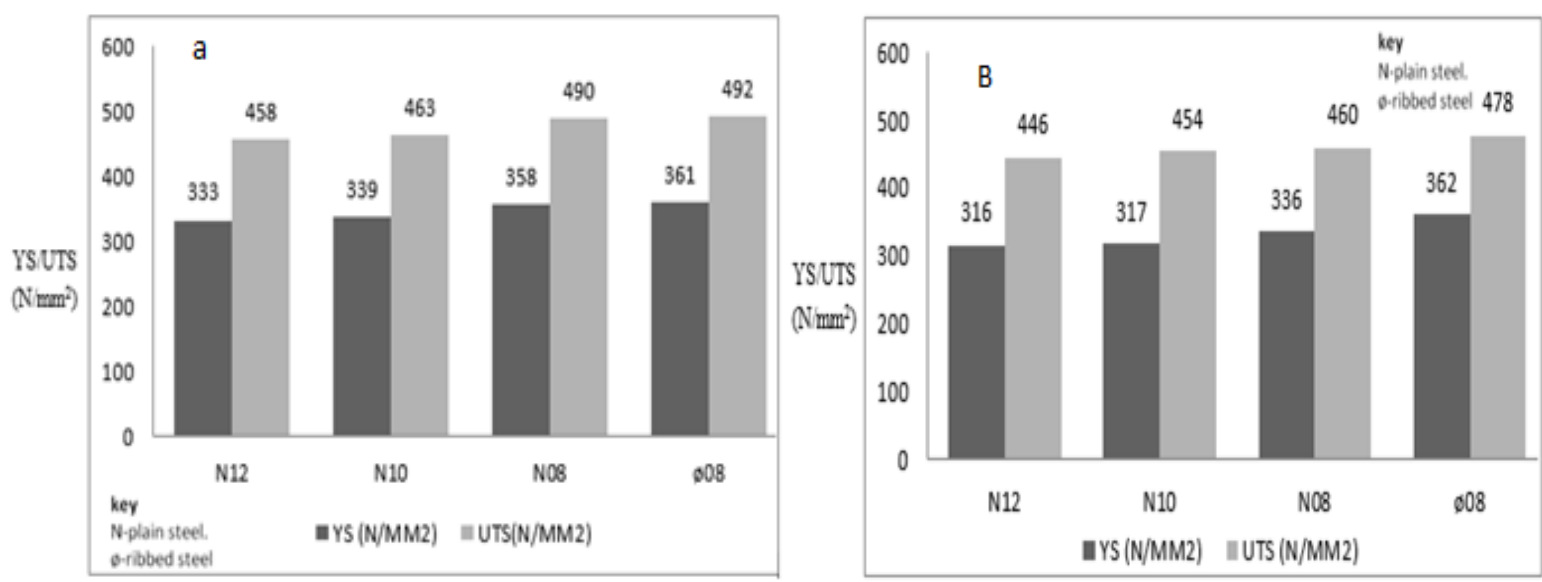

Fig 2: Response chart of hot rolled steel rod for the yield and ultimate tensile strength to profile for heat number (a) 43 (b) 45

Conclusion: The results of this research work showed that the chemical compositions of the hot rolled 3PS steel rod conform to industry standard as supplied by the manufacturer. The yield and ultimate tensile strength reach maximum value of $492 \mathrm{~N} / \mathrm{mm}^{2}$ and $361 \mathrm{~N} / \mathrm{mm}^{2}$ for heat number 43 while $478 \mathrm{~N} / \mathrm{mm}^{2}$ and $362 \mathrm{~N} / \mathrm{mm}^{2}$ for heat number 56 at both a profile of $8 \mathrm{~mm}$. The ribbed steel rod of the same diameter as 
plain steel exhibit slightly better mechanical properties with higher values of yield and ultimate tensile strength.

\section{REFERENCE}

Aggen, G., Allen, M., (2018). Properties and Selection: Irons, Steels, and High-Performance Alloys. ASM International: ASM Handbook, vol. 1: The Materials Information Company

Aghamir MS. Oono, N., Ukai S., Kasada R., Noto H., Hishinuma Y., Muroga T. (2018). Microstructure and Mechanical Properties of Mechanically Alloyed ODS Copper Alloy for Fusion Material Application, Nucl. Mater. Energy 15: 17-22

Atanda, O. P, Abioye A. A Iyiola AO (2015). Mechanical Behaviour and Microstructural Characterization of Carbon Steel Samples from Three Selected Steel Rolling Plants, American J. Eng. Res. 11 (4) : 47-56

Bell. T., (2017). Steel applications. 2017 August 20 [cited 2018 10th February]; Available from: https://www.thebalance.com/steel-applications2340171

Callister Jr., WD., Rethwisch, DG (2012). Fundamentals of Materials Science and Engineering: An Integrated Approach John Wiley \& Sons

Charlie RB (1996). Principales of the Heat Treatment of Plain Carbon and Low Alloy Steels, ASM International, Materials Park

Cheng WC., Song YS., Lin YS., Chen KF., Pistorius PC (2013) The Eutectoid Reaction in a Quaternary Fe-C-Mn-Al alloy: Austenite Ferrite KappaCarbide 23C6 Carbide, Metall. Mater. Trans. 45 (3): 1199-1216
Hata H., Nagao M., Minamida T (2004). High-Carbon Steel Wire Rod with Superior Drawability and Method for Production Thereof, US Patent 6783609

Materials, A. SAE/AISI carbon steel naming conventions July 12, 2012. [Cited 2017 December 23]; Available from: https://www.azom.com/article.aspx?ArticleID=61 51

Mridha, S (2016). Metallic Materials in Reference Module Materials Science and Materials Engineering. Elsevier. 62 (6): 59-76

Obikwelu, (1987). Mettaurgical consideration in the optimization of mechanical properties of rolled products, Seminar Paper Presented at the Metallurgical and Research Department. Delta Steel Company, Aladja, Warri, Nigeria

Ridley N (1984). A Review of the Data on the Interlamellar Spacing of Pearlite. Metall. Mater. Trans A. 15:1019-36

Saroj K. (2010). Optimal Temperature Tracking for Accelerated Cooling Processes in Hot Rolling of Steel J. Dyn Control. 7 (4) 327-340

Zhuang, L. Di, WU. (2006). "Influence of Hot Deformation and Subsequent Austempering on the Mechanical properties of Hot-Rolled Multiphase Steel" J. Mat. Sci. Technol. 22 (6) 230-241

Zhang C.J., X. Zhang Li, Chai S., Chen L., Kong Z., Chen F., Y. (2017). Effects of Direct Rolling Deformation on the Microstructure and Tensile Properties of the 2.5 vol \% (TiBw pTiCp)/Ti Composites, Mater. Sci. Eng., 9(2) 645-651 